\title{
Hubungan antara Locus of Control dan Persepsi Siswa tentang Pendidikan dengan Motivasi Belajar serta Implikasinya dalam Pelayanan Bimbingan dan Konseling
}

\author{
Mona Yulia Zulfa ${ }^{1}$, Daharnis ${ }^{2}$, Syahniar ${ }^{3}$ \\ ${ }^{123}$ Universitas Negeri Padang
}

\begin{abstract}
Abstrak
The background of this research was the lack of student's learning motivation. Locus of control and student's perception about education became factors that can predict student's learning motivation. This research is aimed to describe: (1) locus of control, (2) student's perception about education, (3) learning motivation, and examine: (4) the relationship between locus of control with learning motivation, (5) the relationship between student's perception about education with learning motivation, and (6) the relationship between locus of control and student's perception about education with learning motivation. This research applied quantitative method with a descriptive correlational. The populations of this research were 623 students of SMA Pertiwi 1 Padang in grade X and XI and the samples were 243 students, that were chosen by using proportional stratified random sampling technique. The instrument of the research was a model likert scale. The implication of this research can be made as a need assessment to make a program of guidance dan counseling service in SMA Pertiwi 1 Padang.
\end{abstract}

Kata Kunci: Pendekatan kontekstual, peningkatan pembelajaran, pembelajaran IPA Indonesian Institute for Counseling, Education and Therapy (IICET).

\section{PENDAHULUAN}

Pada masa sekarang ini generasi muda diharuskan memiliki pengetahuan yang tinggi sehingga tidak ketinggalan dalam perkembangan zaman. Seseorang harus memiliki kualitas yang baik dalam segala aspek karena semakin tingginya tuntutan dan persaingan dunia kerja yang membutuhkan sumber daya manusia yang berkualitas. Peningkatan sumber daya manusia salah satunya melalui pendidikan. Pendidikan merupakan proses mencetak generasi penerus bangsa yang akan membantu dalam kemajuan Negara. Tidak dapat dibayangkan jika penerus bangsa ini tidak memiliki pendidikan yang layak maka kemajuan negara akan sulit tercapai. Pendidikan pada hakikatnya bertujuan untuk menciptakan sumber daya manusia yang mandiri dan berkompetensi dalam mengisi dan berpartisipasi aktif dalam pembangunan nasional.

Tujuan pendidikan memuat nilai-nilai yang baik, luhur, pantas, benar, dan indah untuk kehidupan. Karena itu, tujuan pendidikan memiliki dua fungsi yaitu memberikan arah kepada segenap kegiatan dan merupakan sesuatu yang ingin dicapai oleh segenap kegiatan pendidikan (Tirtarahardja dan La Sulo, 2008:37). Pencapaian tujuan pendidikan tersebut salah satunya adalah melalui pendidikan di sekolah. Dalam keseluruhan proses pendidikan di sekolah, kegiatan belajar merupakan kegiatan paling pokok. Sekolah sebagai lembaga pendidikan formal mempunyai tugas menyelenggarakan pendidikan melalui proses pembelajaran untuk mengembangkan aspek 
kemanusiaan dan potensi diri siswa, sehingga siswa nantinya dapat berkembang sesuai dengan potensi yang dimilikinya. Hal ini tentunya tidak terlepas dari motivasi siswa itu sendiri dalam menjalani pendidikan tersebut.

Crider dkk. (1983:121) menjelaskan bahwa, "Motivation can be defined as the desires, needs, and interests that arouse or activate an organism and direct it toward a specific goal, can lead to many different behaviors". Motivasi dapat didefinisikan sebagai keinginan, kebutuhan, dan kepentingan yang membangkitkan atau mengaktifkan suatu organisme dan mengarahkan ke arah tujuan tertentu, dapat menyebabkan banyak perilaku yang berbeda. Lebih lanjut motivasi menurut Mangkuprawira dan Hubeis (2007:113) merupakan dorongan yang membuat individu melakukan sesuatu dengan cara dan untuk mencapai tujuan tertentu. Motivasi dalam bahasa Inggris disebut motivation yang berasal dari bahasa latin movere yang berarti menggerakkan. Adanya motivasi yang tinggi dari siswa diharapkan mampu menggerakkan minat siswa untuk menjadikan sekolah bukan hanya sebagai tuntutan namun juga merupakan kebutuhan bagi dirinya.

Berdasarkan pendapat para ahli di atas, dapat disimpulkan bahwa motivasi merupakan suatu dorongan dari dalam diri individu dan luar diri individu yang menyebabkan individu bergerak untuk melakukan suatu hal dalam mencapai hasrat dan tujuan tertentu. Dalam hal belajar, motivasi diartikan sebagai keseluruhan daya penggerak dalam diri siswa untuk melakukan serangkaian kegiatan belajar guna mencapai tujuan yang telah ditetapkan.

Sekolah memiliki visi dan misi untuk meningkatkan motivasi belajar dan juga prestasi belajar siswa atau meningkatkan sumber daya manusia, tetapi pada kenyataannya banyak siswa yang tidak memperhatikan hal tersebut, mereka menganggap sekolah itu sebagai ajang bertemu teman-teman dan bisa keluar dari rumah saja tanpa memperhatikan apa sesungguhnya yang mereka cari ke sekolah, dan kenyataan tersebut ditemui di SMA Pertiwi 1 Padang. Sehubungan dengan motivasi belajar siswa beberapa tahun belakangan ini, muncul beberapa fenomena atau gelaja yang memprihatinkan, seperti terlihat pada absensi siswa dalam mengikuti proses pembelajaran, banyaknya siswa yang alfa, sering terlambat untuk datang ke sekolah, dan cabut ketika proses pembelajaran berlangsung.

Berdasarkan hasil obeservasi, terlihat banyaknya siswa yang keluar masuk ketika proses pembelajaran berlangsung, banyak yang pergi ke kedai dan minta izin kepada guru BK untuk duduk di ruangan BK, dan ketika mereka diberi tugas oleh guru, kebanyakan mereka tidak mengerjakan tugas tersebut. Setelah diwawancarai, kebanyakan mereka menjawab karena mereka bosan dalam belajar. Hal ini menunjukkan bahwa rendahnya motivasi belajar siswa.

Beberapa hal yang diduga menjadi faktor yang mempengaruhi motivasi belajar seperti yang dikemukakan oleh Elliott dkk. (1996:342) yaitu anxiety (kecemasan), attitudes (sikap), curiosity (keingintahuan), locus of control (sejauhmana seseorang merasa bahwa dirinya atau faktor dari luar dirinya dapat mengendalikan peristiwa yang terjadi dan mempengaruhi kehidupan), learned helplessness (kekurangmampuan dalam belajar), self efficacy (keyakinan diri), dan cooperative learning (pembelajaraan kooperatif).

Suryabrata (2012:12) menyatakan bahwa salah satu faktor yang mempengaruhi motivasi belajar adalah persepsi. Tinggi rendahnya motivasi belajar siswa juga dapat dipengaruhi oleh bagaimana individu memandang peristiwa-peristiwa dalam kehidupannya sebagai konsekuensi perbuatannya (locus of control). Locus of control menggambarkan seberapa jauh individu memandang hubungan antara perbuatan yang dilakukannya dengan akibat atau hasil yang dicapainya. Rotter (dalam Loice, 2014:02) menjelaskan, "Locus of control as the extent to which people perceive that them or external factors such as chance and powerful others are in control of the events that influence their lives". Locus of control adalah sejauhmana seseorang merasa bahwa dirinya atau faktor dari luar dirinya seperti kesempatan dan kekuatan lain, dapat mengendalikan peristiwa yang terjadi dan mempengaruhi kehidupan mereka. Locus of control mempengaruhi motivasi belajar terlihat juga dari hasil penelitian Mugiarso dan Suharso (2013) bahwa seseorang yang cenderung memiliki locus of control internal, berarti seseorang tersebut memiliki motivasi yang tinggi. 
Locus of control terdiri dari dua dimensi yaitu internal dan eksternal. Siswa yang memiliki kecenderungan locus of control internal meyakini bahwa kesuksesan dan kegagalannya dalam belajar adalah hasil dari tindakan dan usaha mereka sendiri (Rotter, 1996:4). Contohnya ketika siswa memiliki nilai yang rendah meyakini bahwa tidak belajar dengan optimal, bukan karena gurunya yang pilih kasih. Sebaliknya siswa yang memiliki kecenderungan locus of control eksternal akan meyakini bahwa kesuksesan dan kegagalannya adalah karena faktor di luar dirinya.

Faktor lain yang juga mempengaruhi motivasi belajar siswa adalah persepsi siswa itu sendiri tentang pendidikan. Menurut Leavitt (dalam Sobur, 2003:445), persepsi (perception) dalam arti sempit ialah penglihatan, bagaimana cara seseorang melihat sesuatu, sedangkan dalam arti luas ialah pandangan atau pengertian, yaitu bagaimana seseorang memandang atau mengartikan sesuatu. Persepsi menurut Feldmen, Sternberg, dan Robbins (dalam Nirwana, 2003:50) merupakan proses ketika individu mengorganisasikan, mengenal, dan memaknai sensasi yang diperolehnya dari lingkungan. Maksud dari pernyataan tersebut adalah persepsi merupakan bagaimana seseorang memandang dan memaknai suatu hal yang diperoleh dari lingkungan.

Berkaitan dengan sekolah, persepsi siswa tentang pendidikan dijelaskan sebagai pandangan atau anggapan siswa mengenai pendidikan itu sendiri, bagus atau tidaknya pendidikan tersebut. Persepsi siswa tentang pendidikan yang tidak positif akan membuat kurangnya motivasi siswa dalam belajar, begitu juga sebaliknya persepsi siswa yang positif tentang pendidikan akan membuat motivasi belajar siswa yang tinggi juga. Hal ini senada dengan hasil penelitian dari Megawati (2015), yang menyatakan bahwa semakin positif persepsi siswa, maka akan semakin menumbuhkan motivasi belajar yang tinggi pada siswa, dan semakin tidak positif persepsi siswa, maka akan semakin rendah juga motivasi belajar siswa tersebut. Dapat disimpulkan bahwa salah satu faktor yang mempengaruhi motivasi belajar adalah persepsi siswa tentang pendidikan.

Berdasarkan penjelasan di atas, dapat disimpulkan bahwa motivasi belajar menjadi hal yang sangat perlu diperhatikan dan penting. Oleh karena itu, bimbingan dan konseling memiliki peranan yang penting dalam usaha membantu siswa untuk meningkatkan locus of control internal dan persepsi yang positif tentang pendidikan, yang bertujuan agar siswa memiliki motivasi belajar yang tinggi. Hal ini dapat dilakukan dengan pelaksanaan layanan bimbingan dan konseling kepada siswa, seperti: layanan orientasi, layanan informasi, layanan konseling perorangan, bimbingan kelompok, dan layanan lainnya. Dalam pelaksanaan layanan konseling tersebut, konselor harus mengetahui berbagai faktor yang mempengaruhi motivasi belajar pada siswa, diantaranya locus of control dan persepsi siswa tentang pendidikan. Untuk membuktikan seberapa besar hubungan dari faktor-faktor tersebut dalam meningkatkan motivasi belajar siswa, peneliti tertarik untuk melakukan penelitian tentang hubungan antara locus of control dan persepsi siswa tentang pendidikan dengan motivasi belajar siswa serta implikasinya dalam pelayanan bimbingan dan konseling.

Tujuan penelitian ini yaitu: (1) mendeskripsikan gambaran locus of control, persepsi siswa tentang pendidikan, dan motivasi belajar siswa, (2) menguji hubungan antara locus of control dengan motivasi belajar siswa, (3) menguji hubungan antara persepsi siswa tentang pendidikan dengan motivasi belajar siswa, (4) menguji hubungan antara locus of control dan persepsi siswa tentang pendidikan secara bersama-sama dengan motivasi belajar siswa.

\section{METODE}

Penelitian ini menggunakan metode kuantitatif jenis deskriptif korelasional. Populasi penelitian adalah siswa kelas X dan XI SMA Pertiwi 1 Padang yang berjumlah 623 orang, sampel berjumlah 243 orang, yang dipilih dengan teknik proportional stratified random sampling. Instrumen yang digunakan adalah skala model likert. Data dianalisis dengan statistik deskriptif, regresi sederhana dan ganda. Analisis data dibantu dengan menggunakan program SPSS versi 20.00 . 
HASIL

Deskripsi Data

Data dalam penelitian ini meliputi variabel locus of control (X1), persepsi siswa tentang pendidikan (X2), dan motivasi belajar (Y). Berikut ini dikemukakan deskripsi data hasil penelitian.

\section{Locus of Control $\left(\mathrm{X}_{1}\right)$}

Secara keseluruhan jumlah item pernyataan variabel locus of control ada sebanyak 24 butir item, rentangan skor dari 1-5, dengan skor tertinggi adalah 120 dan skor terendah adalah 24 . Kriteria skala locus of control yang berjumlah 243 responden dapat dilihat pada Tabel 1.

Tabel 1. Distribusi Frekuensi dan Persentase Locus of Control

\begin{tabular}{clcc}
\hline Interval Skor & \multicolumn{1}{c}{ Kategori } & Frekuensi & \% \\
\hline$\geq \mathbf{1 0 1}$ & Sangat Tinggi & 0 & 0 \\
$\mathbf{8 2} \mathbf{- 1 0 0}$ & Tinggi & 116 & 47,74 \\
$\mathbf{6 3 - 8 1}$ & Sedang & 127 & 52,26 \\
$\mathbf{4 4 - 6 2}$ & Rendah & 0 & 0 \\
$\leq \mathbf{4 3}$ & Sangat Rendah & 0 & 0 \\
& \multicolumn{1}{c}{ Total } & 243 & 100 \\
\hline
\end{tabular}

Tabel 1 di atas memperlihatkan bahwa sebagian besar siswa memiliki locus of control dalam kategori sedang. Namun demikian, masih terdapat variasi skor dalam indikator locus of control.

\section{Persepsi Siswa tentang Pendidikan $\left(\mathbf{X}_{2}\right)$}

Secara keseluruhan jumlah item pernyataan variabel persepsi siswa tentang pendidikan ada sebanyak 30 butir item, rentangan skor dari 1-5, dengan skor tertinggi adalah 150 dan skor terendah adalah 30 . Kriteria skala persepsi siswa tentang pendidikan yang berjumlah 243 responden dapat dilihat pada Tabel 2.

Tabel 2. Distribusi Frekuensi dan Persentase Persepsi Siswa Pendidikan

\begin{tabular}{clcc}
\hline Interval Skor & \multicolumn{1}{c}{ Kategori } & Frekuensi & \% \\
\hline $\mathbf{2 1 2 6}$ & Sangat Positif & 150 & 62 \\
$\mathbf{1 0 2} \mathbf{- 1 2 5}$ & Positif & 84 & 34,57 \\
$\mathbf{4 3 - 5 6}$ & Cukup Positif & 9 & 3,70 \\
$\mathbf{2 9} \mathbf{- 4 2}$ & Tidak Positif & 0 & 0 \\
$\leq \mathbf{2 8}$ & Sangat Tidak Positif & 0 & 0 \\
& Total & 243 & 100 \\
\hline
\end{tabular}

Tabel 2 di atas memperlihatkan bahwa sebagian besar siswa memiliki persepsi yang sangat positif tentang pendidikan. Namun demikian, masih terdapat variasi skor dalam indikator persepsi siswa tentang pendidikan.

\section{Motivasi Belajar (Y)}

Secara keseluruhan jumlah item pernyataan variabel persepsi siswa tentang pendidikan ada sebanyak 26 butir item, rentangan skor dari 1-5, dengan skor tertinggi adalah 130 dan skor terendah adalah 26. Kriteria skala motivasi belajar yang berjumlah 243 responden dapat dilihat pada Tabel 3 . 
Tabel 3. Distribusi Frekuensi dan Persentase Motivasi Belajar

\begin{tabular}{clcc}
\hline Interval Skor & \multicolumn{1}{c}{ Kategori } & Frekuensi & \% \\
\hline $\mathbf{2 1 1 0}$ & Sangat Tinggi & 29 & 12 \\
$\mathbf{8 9} \mathbf{- 1 0 9}$ & Tinggi & 103 & 42,39 \\
$\mathbf{6 8 - \mathbf { 8 8 }}$ & Sedang & 103 & 42,39 \\
$\mathbf{4 7 - \mathbf { 6 7 }}$ & Rendah & 8 & 3.29 \\
$\leq \mathbf{4 6}$ & Sangat Rendah & 0 & 0 \\
& Total & 243 & 100 \\
\hline
\end{tabular}

Tabel 3 di atas memperlihatkan bahwa sebagian besar motivasi belajar berada pada kategori tinggi dan sedang. Secara rata-rata capaian terhadap skor ideal adalah berada pada kategori tinggi. Namun demikian, masih terdapat variasi skor dalam indikator motivasi belajar.

\section{Pengujian Persyaratan Analisis Data}

Uji persyaratan analisis yang dilakukan pada data penelitian ini adalah uji normalitas, uji linieritas, dan uji multikolinieritas.

\section{Uji Normalitas}

Hasil uji normalitas data menggunakan uji Kolmogorov-Smirnov, dengan nilai Asymp. Sig. locus of control sebesar 0,079, persepsi siswa tentang pendidikan sebesar 0,264, dan motivasi belajar sebesar 0,292. Berarti ketiga data variabel penelitian berdistribusi normal.

\section{Uji Linieritas}

Berdasarkan hasil uji linieritas, didapatkan hasil bahwa hubungan locus of control dengan motivasi belajar adalah linier dengan $F_{\text {hitung }}(10,774)>F_{\text {tabel }}(3,89)$. Data hubungan persepsi siswa tentang pendidikan dengan motivasi belajar juga linier dengan $F_{\text {hitung }}(54,722)>F_{\text {tabel }}$ $(3,89)$.

\section{Uji Multikolinieritas}

Hasil uji multikolinieritas menunjukkan bahwa tidak terjadi multikolinieritas antara variabel locus of control dengan persepsi siswa tentang pendidikan, dengan nilai VIP locus of control sebesar 1,033 dan nilai VIP persepsi siswa tentang pendidikan sebesar $1,033<5$.

Hubungan antara Locus of Control dan Persepsi Siswa tentang Pendidikan dengan Motivasi Belajar

\section{Hubungan antara Locus of Control dengan Motivasi Belajar}

Hasil analisis hubungan antara locus of control dengan motivasi belajar dapat dilihat pada Tabel 4.

Tabel 4. Hasil Analisis Regresi Sederhana dan Uji Signifikansi $X_{1}$ dengan $Y$

\begin{tabular}{cccc}
\hline Model & $\mathbf{R}$ & $\boldsymbol{R}$ Square & Sig. \\
\hline $\mathbf{X}_{\mathbf{1}}-\mathbf{Y}$ & 0,200 & 0,040 & 0,002 \\
\hline
\end{tabular}

Pada Tabel 4 dapat dilihat bahwa nilai $\mathrm{R}$ sebesar 0,200 yang menunjukkan koefisien korelasi antara locus of control dengan motivasi belajar, dengan taraf signifikan 0,002. Nilai $R$ Square $\left(R^{2}\right)$ sebesar 0,040 ini berarti $4 \%$ variasi tinggi-rendahnya motivasi belajar dapat dijelaskan oleh locus of control, sedangkan sisanya $96 \%$ dijelaskan oleh variabel lain. 


\section{Hubungan antara Persepsi Siswa tentang Pendidikan dengan Motivasi Belajar}

Hasil analisis hubungan antara persepsi siswa tentang pendidikan dengan motivasi belajar dapat dilihat pada Tabel 5.

Tabel 5. Hasil Analisis Regresi Sederhana dan Uji Signifikansi $X_{2}$ dnegan $Y$

\begin{tabular}{cccc}
\hline Model & $\mathbf{R}$ & $\boldsymbol{R}$ Square & Sig. \\
\hline $\mathbf{X}_{\mathbf{2}}-\mathbf{Y}$ & 0,432 & 0,186 & 0,000 \\
\hline
\end{tabular}

Pada Tabel 5 dapat dilihat bahwa nilai $\mathrm{R}$ sebesar 0,432 yang menunjukkan koefisien korelasi antara persepsi siswa tentang pendidikan dengan motivasi belajar, dengan taraf signifikan 0,000. Nilai $R$ Square $\left(R^{2}\right)$ sebesar 0,186 , ini berarti $18,6 \%$ variasi tinggi rendahnya motivasi belajar dapat dijelaskan oleh persepsi siswa tentang pendidikan, sedangkan sisanya $81,4 \%$ dijelaskan oleh variabel lain.

\section{Hubungan antara Locus of Control dan Persepsi Siswa tentang Pendidikan dengan Motivasi Belajar}

Hasil analisis hubungan antara locus of control dan persepsi siswa tentang pendidikan dengan motivasi belajar dapat dilihat pada Tabel 6.

\section{Tabel 6. Hasil Analisis Regresi Ganda dan Uji Signifikansi $X_{1}$ dan $X_{2}$ dengan $Y$}

\begin{tabular}{lrrrl}
\hline Model & $\mathbf{R}$ & $\boldsymbol{R}$ Square & Sig. \\
\hline $\mathbf{X}_{\mathbf{1}}, \mathbf{X}_{\mathbf{2}}-\mathbf{Y}$ & & 0,449 & 0,202 & 0,000 \\
\hline
\end{tabular}

Pada Tabel 6 dapat dilihat bahwa nilai $\mathrm{R}$ sebesar 0,449 yang menunjukkan koefisien regresi ganda antara locus of control dan persepsi siswa tentang pendidikan dengan motivasi belajar, dengan taraf signifikan 0,000 . Nilai $R$ Square $\left(R^{2}\right)$ sebesar 0,202 , ini berarti $20,2 \%$ variasi tinggi rendahnya motivasi belajar dapat dijelaskan secara bersama-sama oleh locus of control dan persepsi siswa tentang pendidikan, sedangkan sisanya 79,8\% dijelaskan oleh variabel lain yang belum diteliti dalam penelitian ini

\section{PEMBAHASAN}

\section{Locus of Control}

Hasil analisis data penelitian menunjukkan bahwa rata-rata secara keseluruhan siswa memiliki tingkat internal locus of control dalam kategori sedang. Hal ini berarti locus of control siswa cukup bagus. Berdasarkan pencapaian masing-masing indikator diketahui bahwa indikator internality berada pada kategori tinggi, sedangkan indikator powerful others dan chance berada pada kategori sedang. Kondisi locus of control (internality) yang tinggi ini perlu untuk terus dipertahankan, dikembangkan, dan ditingkatkan, karena locus of control merupakan suatu hal yang kompleks terkhusus dalam meningkatkan motivasi belajar.

Locus of control merupakan pandangan seorang individu terhadap dirinya, berkaitan dengan usaha dan hasil yang diterima. Setiap siswa mempunyai kecenderungan locus of control yang berbeda-beda, ada yang internal dan ada yang eksternal. Rotter (1966:19) mengungkapkan karakteristik locus of control internal siswa antara lain: perhatian yang penuh terhadap sesuatu, kompeten, dapat melawan dan mengatasi pengaruh dari luar, berorientasi pada prestasi, cekatan, dan percaya pada kemampuan sendiri. Hal tersebut terlihat jelas pada indikator internality bahwa siswa merasa yakin bahwa segala usaha dan hasil yang diterima ditentukan oleh kemampuan usaha sendiri. Rata-rata keluruhan siswa mencapai kategori tinggi, dan sangat tinggi. Ini menunjukkan bahwa rata-rata keseluruhan siswa sudah memiliki locus of control internal dan hal ini perlu dikembangkan. Selanjutnya dapat sebagai acuan 
bagi guru BK khususnya dalam mengarahkan siswa agar dapat mengembangkan locus of control internal tersebut dalam kehidupan sehari-hari siswa.

Di samping itu, capaian sedang pada indikator lainnya (powerful other dan chance) yang merupakan indikator yang mengarah pada locus of control eksternal perlu diperhatikan oleh guru BK pada khususnya dalam mengarahkan siswa kepada locus of control internal. Siswa dengan locus of control eksternal berorientasi bahwa apa yang terjadi dalam hidupnya itu semua dipengaruhi oleh orang lain, keberuntungan, dan nasib yang diluar kendali mereka.

Berdasarkan data penelitian ini guru BK atau Konselor memegang peranan penting untuk mengarahkan locus of control siswa ke arah locus of control internal. Melalui pelayanan BK yang profesional diharapkan guru BK atau Konselor mampu mempertahankan, mengembangkan, maupun meningkatkan locus of control siswa. Hal ini dapat dilakukan oleh guru BK melalui layanan informasi dan layanan konseling individual. Dengan menginformasikan kepada siswa bagaimana pentingnya meningkatkan locus of control internal dalam kehidupan sehari-hari agar siswa menjadi pribadi yang mandiri dan pribadi yang percaya akan kemampuan sendiri serta sukses dalam belajar. Berdasarkan paparan tersebut dapat dipahami bahwa layanan informasi dan layanan konseling individual dapat dijadikan alternatif pelayanan oleh guru BK atau Konselor untuk meningkatkan locus of control siswa.

\section{Persepsi Siswa Pendidikan}

Berdasarkan hasil analisis data penelitian, bahwa secara rata-rata keseluruhan persepsi siswa tentang pendidikan berada pada kategori sangat positif. Pencapaian indikator pentingnya pendidikan dan tujuan dari pendidikan berada pada kategori sangat positif dan pencapaian pada indikator manfaat pendidikan berada pada kategori positif. Siswa memiliki persepsi yang sangat positif tentang pendidikan dikarenakan siswa mengetahui dan memahami akan arti pentingnya pendidikan tersebut.

Secara utuh siswa telah mengenali dan menyadari akan arti penting dan tujuan dari pendidikan. Hal tersebut sesuai dengan pendapat Sternberg (2008:105) bahwa persepsi individu tentang sesuatu bukan hanya berasal dari tindakan mental, namun melibatkan proses yang panjang dimulai dari mengenali, mengorganisasikan, sampai pada memahami respon melalui tangkapan indera yang diterima dari lingkungan sekitar.

Berdasarkan rata-rata capaian persepsi siswa tentang pendidikan yang sangat positif, memberikan gambaran bahwa sangat bagusnya persepsi siswa tentang pendidikan dan hal ini menjadi acuan dan perhatian khusus bagi guru BK dalam mengarahkan siswa agar siswa mampu mempertahankan dan mengembangkan persepsi siswa yang sangat positif tentang pendidikan. Dalam hal ini yang perlu menjadi perhatian oleh guru BK adalah mengenai hasil dari indikator manfaat pendidikan yang berada pada kategori positif, dalam arti bagus. Guru BK berupaya mengarahkan agar siswa mampu meningkatkan persepsi tentang manfaat pendidikan tersebut pada kategori sangat positif, karena semakin lebih positif tentunya semakin bagus persepsi siswa tentang manfaat pendidikan.

Merujuk pada penelitian Afnibar (2011) secara konkret beberapa layanan yang dapat digunakan oleh guru BK atau Konselor untuk mengubah persepsi siswa tentang pendidikan menjadi lebih positif antara lain: layanan informasi, penempatan penyaluran, orientasi, maupun penguasaan konten. Layanan-layanan tersebut tentunya didukung oleh materi-materi yang sesuai dengan akan arti pentingnya pendidikan, tujuan dan manfaat pendidikan.

\section{Motivasi Belajar}

Hasil analisis data penelitian menunjukkan bahwa secara rata-rata keseluruhan motivasi belajar berada pada kategori tinggi. Berdasarkan pencapaian masing-masing indikator diketahui bahwa indikator tekun dalam mengerjakan tugas dan menunjukkan minat berada pada ketegori tinggi, sedangkan indikator ulet dalam menghadapi kesulitan dan mandiri dalam belajar berada pada kategori sedang. 
Hal ini terlihat jelas bahwa masih adanya motivasi belajar siswa yang rendah dan tentunya ada berbagai faktor yang menyebabkan rendahnya motivasi belajar siswa tersebut. Secara ratarata keseluruhan memang motivasi belajar siswa berada pada ketegori tinggi, namun karena ada beberapa item yang berada pada kategori sedang, tentunya hal tersebut perlu dibahas.

Motivasi belajar dalam kategori tinggi ini perlu dipertahankan dan lebih dikembangkan oleh siswa. Sedangkan motivasi belajar yang sedang perlu menjadi perhatian khusus oleh guru BK. Syah (2001:108) mengemukakan bahwa motivasi belajar dipengaruhi oleh 2 faktor, yaitu: (1) faktor internal yang meliputi sikap, kepribadian, pendidikan, pengalaman, dan cita-cita, (2) faktor eksternal yang meliputi lingkungan sosial, yang terdiri dari lingkungan masyarakat, tetangga, teman, orangtua/keluarga, dan teman sekolah. Lingkungan non sosial, yang terdiri dari keadaan gedung sekolah, letak sekolah, jarak tempat tinggal dengan sekolah, alat-alat belajar, kondisi ekonomi orangtua, dan lain-lain. Beberapa faktor yang lain selain dari locus of control dan persepsi tersebut kemungkinan juga mempengaruhinya motivasi belajar.

Berbagai faktor tersebut dapat sebagai acuan oleh guru BK untuk menindaklanjuti lebih lanjut hal apa yang mempengaruhi motivasi belajar siswa tersebut. Guru BK dapat memberikan layanan informasi, konseling individual, bimbingan kelompok, konseling kelompok dan penguasaan konten terhadap siswa.

\section{Hubungan antara Locus of Control dengan Motivasi Belajar}

Hasil penelitian menunjukkan bahwa locus of control memiliki hubungan yang signifikan dengan motivasi belajar. Temuan ini diperoleh berdasarkan rangkaian analisis data, yang menunjukkan bahwa 4\% motivasi belajar dijelaskan oleh locus of control. Artinya, locus of control merupakan salah satu faktor yang berhubungan dengan motivasi belajar. Hal ini juga sesuai dengan pendapat Elliot dkk. (1996:342) bahwa locus of control merupakan salah satu faktor yang mempengaruhi motivasi belajar. Selanjutnya hal ini juga sesuai dengan hasil penelitian dari Mugiarso dan Suharso (2013), yang menyatakan bahwa seseorang yang cenderung memiliki locus of control internal, berarti seseorang tersebut memiliki motivasi yang tinggi, dalam arti terdapatnya hubungan yang signifikan antara locus of control dengan motivasi belajar.

Selanjutnya, hasil penelitian ini memberikan gambaran bahwa meskipun hubungan antara locus of control dengan motivasi belajar hanya 4\%, hal ini tidak serta merta dapat diabaikan, karena sudah terbukti bahwa locus of control akan mendorong siswa untuk dapat meningkatkan motivasi belajarnya.

Oleh sebab itu, guru BK atau Konselor mempunyai peranan yang cukup strategis terhadap hal ini. Guru BK atau Konselor harus tetap mengembangkan dan meningkatkan locus of control siswa, agar siswa dapat meningkatkan motivasi belajarnya. Melalui pelayanan BK yang optimal locus of control siswa harus terus dikembangkan, karena secara langsung berdampak pada motivasi belajar siswa. Salah satu layanan yang dapat digunakan guru BK atau Konselor untuk meningkatkan motivasi belajar siswa adalah layanan informasi, dengan memberikan berbagai informasi-informasi terkait dengan pentingnya percaya akan suatu usaha dan hasil yang diperoleh merupakan upaya yang dilakukan oleh diri sendiri agar siswa menjadi pribadi yang selalu dapat memotivasi dirinya sendiri dalam belajar.

\section{Hubungan Persepsi Siswa tentang Pendidikan dengan Motivasi Belajar}

Hasil penelitian menunjukkan bahwa persepsi siswa tentang pendidikan memiliki hubungan yang signifikan dengan motivasi belajar. Temuan ini diperoleh berdasarkan rangkaian analisis data, yang menunjukkan bahwa 18,6\% motivasi belajar dijelaskan oleh persepsi siswa tentang pendidikan. Artinya, persepsi siswa tentang pendidikan merupakan salah satu faktor yang berhubungan dengan motivasi belajar.

Merujuk pada data penelitian ini dapat dipahami bahwa semakin positif persepsi siswa tentang pendidikan maka akan semakin tinggi pula motivasi belajar siswa. Hal ini sesuai dengan temuan penelitian Megawati (2015) yang menyatakan bahwa semakin positif persepsi 
siswa, maka akan semakin menumbuhkan motivasi belajar yang tinggi pada siswa, dan semakin tidak positif persepsi siswa, maka akan semakin rendah juga motivasi belajar siswa tersebut. Dapat disimpulkan bahwa salah satu faktor yang mempengaruhi motivasi belajar adalah persepsi siswa tentang pendidikan.

Berdasarkan pemaparan di atas, dapat dipahami bahwa begitu berpengaruhnya persepsi siswa tentang pendidikan dalam meningkatkan motivasi belajar siswa. Tingginya motivasi belajar siswa salah satunya dipengaruhi oleh persepsi siswa tentang pendidikan. Oleh sebab itu, guru BK atau Konselor perlu memahami bahwa untuk meningkatkan motivasi belajar siswa, persepsi siswa tentang pendidikan terlebih dahulu yang harus diubah menjadi lebih positif, sesuai dengan pendapat Sarwono (2012:86) bahwa persepsi merupakan tahap awal siswa dalam menginterpretasikan sesuatu. Guru BK atau konselor dapat memberikan layanan informasi berupa pentingnya pendidikan dan apa manfaat dari pendidikan tersebut, agar siswa dapat meningkatkan motivasi belajarnya.

\section{Hubungan Locus of Control dan Persepsi Siswa tentang Pendidikan dengan Motivais Belajar}

Hasil penelitian menunjukkan bahwa locus of control dan persepsi siswa tentang pendidikan secara bersama-sama memiliki hubungan yang signifikan dengan motivasi belajar. Temuan ini diperoleh berdasarkan rangkaian analisis data, yang menunjukkan bahwa 20,2\% motivasi belajar dijelaskan oleh locus of control dan persepsi siswa tentang pendidikan. Berdasarkan hasil penelitian diperoleh gambaran bahwa locus of control dan persepsi siswa tentang pendidikan tidak terlalu berbeda memiliki hubungan dengan motivasi belajar. Jika membandingkan keduanya maka persepsi siswa tentang pendidikan memiliki hubungan yang kuat dengan motivasi belajar dibandingkan dengan locus of control.

Locus of control merupakan pandangan siswa terhadap dirinya, berkaitan dengan usaha dan hasil yang diterima. Semakin tinggi locus of control siswa maka motivasi belajar siswa pun akan semakin tinggi. Hal ini sesuai dengan pendapat dari Mugiarso dan Suharso (2013), yang menyatakan bahwa seseorang yang cenderung memiliki locus of control internal, berarti seseorang tersebut memiliki motivasi yang tinggi, dalam arti terdapatnya hubungan yang signifikan antara locus of control dengan motivasi belajar.

Selanjutnya persepsi tentang pendidikan merupakan tahap awal yang menentukan meningkatnya motivasi belajar siswa. Dengan semakin positifnya persepsi siswa tentang pendidikan, maka akan semakin meningkatkan motivasi belajar siswa. Hal ini sesuai dengan hasil temuan penelitian Megawati (2015) yang menyatakan bahwa semakin positif persepsi siswa, maka akan semakin menumbuhkan motivasi belajar yang tinggi pada siswa, dan semakin tidak positif persepsi siswa, maka akan semakin rendah juga motivasi belajar siswa tersebut.

Berdasarkan nilai $\mathrm{R}^{2}$ motivasi belajar dijelaskan sebesar $20,2 \%$ oleh locus of control dan persepsi siswa tentang pendidikan, kemudian 79,2\% lagi kemungkinan dijelaskan oleh faktor lain yang belum diteliti pada penelitian ini. Hal ini terlihat bahwa locus of control dan persepsi siswa tentang pendidikan secara bersama-sama tidak terlalu besar mempengaruhi motivasi belajar. Keadaan ini dapat dipahami, karena sesungguhnya masih banyak variabel lainnya yang mempengaruhi motivasi belajar.

Bila merujuk pada teori Elliott dkk. (1996:342) faktor yang mempengaruhi motivasi belajar kemungkinan dari segi lainnya yaitu anxiety (kecemasan), attitudes (sikap), curiosity (keingintahuan), learned helplessness (kekurangmampuan dalam belajar), self efficacy (keyakinan diri), dan cooperative learning (pembelajaraan kooperatif). Dan dapat juga dilihat dari pendapat Syah (2001:108) yang mengemukakan bahwa motivasi belajar dipengaruhi oleh 2 faktor, yaitu: (1) faktor internal yang meliputi sikap, kepribadian, pendidikan, pengalaman, dan cita-cita, (2) faktor eksternal yang meliputi lingkungan sosial, yang terdiri dari lingkungan masyarakat, tetangga, teman, orangtua/keluarga, dan teman sekolah. Lingkungan non sosial, yang terdiri dari keadaan gedung sekolah, letak sekolah, jarak tempat tinggal dengan sekolah, 
alat-alat belajar, kondisi ekonomi orangtua, dan lain-lain. Dapat dikatakan bahwa faktor lainlah yang juga mempengaruhi motivasi belajar selain dari locus of control dan persepsi siswa tentang pendidikan yang peneliti lakukan ini.

Beberapa paparan di atas membuktikan bahwa locus of control dan persepsi siswa tentang pendidikan secara bersama-sama memiliki hubungan yang signifikan dengan motivasi belajar. Dengan demikian untuk meningkatkan motivasi belajar, dapat diupayakan dengan meningkatkan locus of control dan mengupayakan siswa mempunyai persepsi yang positif tentang tentang pendidikan. Guru BK atau Konselor juga berperan dalam memberikan layanan kepada siswa untuk meningkatkan motivasi belajar siswa, seperti layanan konseling individual, dengan menulusuri apa penyebab dari rendahnya motivasi belajar siswa tersebut. Berbagai faktor selain dari locus of control dan persepsi siswa tentang pendidikan yang sudah dijelaskan di atas, dapat dijadikan sebagai acuan bagi guru BK atau Konselor dalam memberikan layanan kepada siswa agar siswa dapat meningkatkan motivasi belajarnya.

\section{KESIMPULAN}

Berdasarkan temuan dan pembahasan hasil penelitian, maka dapat dikemukakan kesimpulan sebagai berikut:

1. Secara rata-rata tingkat internal locus of control siswa SMA Pertiwi 1 Padang berada pada kategori sedang. Hal ini berarti internal locus of control siswa termasuk kategori cukup bagus.

2. Secara rata-rata persepsi siswa SMA Pertiwi 1 Padang tentang pendidikan berada pada kategori sangat positif. Hal ini berarti persepsi siswa tentang pendidikan termasuki kategori sangat bagus.

3. Secara rata-rata motivasi belajar siswa SMA Pertiwi 1 Padang berada pada kategori tinggi. Hal ini berarti motivasi belajar siswa termasuk kategori bagus.

4. Locus of control memiliki hubungan yang signifikan dengan motivasi belajar di SMA Pertiwi 1 Padang. Hasil penelitian menunjukkan koefisien korelasi (R) sebesar 0,200 dan $\mathrm{R}^{2}$ sebesar 0,040, yang berarti bahwa 4\% motivasi belajar dijelaskan oleh locus of control.

5. Persepsi siswa tentang pendidikan memiliki hubungan yang signifikan dengan motivasi belajar di SMA Pertiwi 1 Padang. Hasil penelitian menunjukkan koefisien korelasi (R) sebesar 0,432 dan $\mathrm{R}^{2}$ sebesar 0,186 , yang berarti bahwa $18,6 \%$ motivasi belajar dijelaskan oleh persepsi siswa tentang pendidikan.

6. Locus of control dan persepsi siswa tentang pendidikan secara bersama-sama memiliki hubungan yang signifikan dengan motivasi belajar di SMA Pertiwi 1 Padang. Hasil penelitian menunjukkan koefisien korelasi $(\mathrm{R})$ sebesar 0,449 dan $\mathrm{R}^{2}$ sebesar 0,202 , yang berarti $20,2 \%$ motivasi belajar dijelaskan oleh locus of control dan persepsi siswa tentang pendidikan. Artinya tinggi rendahnya motivasi belajar tidak hanya dipengaruhi oleh satu variabel saja (locus of control dan persepsi siswa tentang pendidikan), namun dipengaruhi secara bersamasama oleh locus of control dan persepsi siswa tentang pendidikan. Atau dengan kata lain dapat dikatakan bahwa semakin tinggi locus of control dan semakin positif persepsi siswa tentang pendidikan, maka semakin tinggi motivasi belajar siswa. Hal ini berarti variabel locus of control dan persepsi siswa tentang pendidikan akan lebih efektif jika dikombinasikan secara bersama-sama sebagai prediktor untuk meningkatkan motivasi belajar daripada hanya satu variabel saja.

\section{SARAN}

Berdasarkan hasil penelitian, pembahasan, dan kesimpulan yang telah dikemukakan sebelumnya, maka terdapat beberapa saran yang dapat direkomendasikan sebagai berikut:

1. Kepada guru BK atau Konselor di sekolah disarankan untuk mengarahkan siswa yang memiliki locus of control eksternal ke arah locus of control internal. Guru BK atau Konselor juga disarankan untuk memberikan arahan dalam meningkatkan motivasi belajar siswa, seperti memberikan arahan bagaimana cara menghadapi tugas yang sulit dan bagaimana supaya siswa dapat mandiri dalam belajar. 
2. Kepada wali kelas dan guru bidang studi di sekolah disarankan agar tetap saling bekerja sama dengan guru BK atau konselor dalam memberikan arahan untuk meningkatkan motivasi belajar siswa.

3. Kepada kepala sekolah disarankan untuk dapat memberikan dukungan penuh kepada guru BK atau Konselor, dengan memfasilitasi sebaik mungkin pelaksanaan masuk kelas 2 jam pembelajaran setiap minggu, maupun pelaksanaan layanan BK di luar jam pembelajaran. Kepala sekolah diharapkan dapat memberikan ruang yang cukup bagi siswa untuk memberikan masukan, kritikan, dan saran dalam rangka meningkatkan motivasi belajar siswa.

\section{DAFTAR RUJUKAN}

Afnibar. 2011. "Model Pelayanan Konseling Format Klasikal dalam Kegiatan Belajar Siswa". Disertasi tidak diterbitkan. Padang: Program Pascasarjana Universitas Negeri Padang.

Crider, A. B. dkk. 1983. Psychology. United State of America: Scott Foresman and Company: United State of America.

Elliott, S. N. dkk. 1996. Educational Psychology: Effective teaching, effective learning. Dubuque: Brown \& Benchmark.

Loice, M. C. 2014. The Influence of Locus of Control on Employees' Perceptions of The Effectiveness of Performance Appraisal at Kenya Revenue Authority (Southern Region). A research Project Submitted in Partial Fulfillmentof the Requirements for the Award of The Degree of Master of Business Administration (MBA), (Online), (www.erepository.ounbi.ac.ke, diakses 11 September 2015).

Mangkuprawira, TB. S. dan Hubeis, A. V. 2007. Manajemen Mutu Sumber Daya Manusia. Bogor: Ghalia Indonesia.

Megawati, L. 2015. "Persepsi Siswa tentang Mata Pelajaran Matematika dan Hubungannya dengan Motivasi Belajar serta Implikasinya dalam Pelayanan Bimbingan Konseling di SMPN 25 Pekanbaru". Tesis tidak diterbitkan. Padang: Pascasarjana FIP UNP.

Mugiarso, C. H dan Suharso. 2013. "Hubungan Locus of Control dengan Motivasi Konselor dalam Layanan Konseling Perorangan”. Journal of Counseling: Theory and Application. Semarang: Universitas Negeri Semarang.

Nirwana, H. 2003. "Hubungan Tingkat Aspirasi dan Persepsi tentang Belajar dengan Hasil Belajar Matematika Siswa Sekolah Menengah Umum yang Berlatar Belakang Budaya Minangkabau dan Batak". Disertasi tidak diterbitkan. Malang: Universitas Negeri Malang.

Rotter, J.B. 1966. Generalized Expectancies for Internal Versus External Control of Reinforcement. American Psychological Association, (Online), Vol. 80, No.1:1-28, (http://www.soc.iastate.edu/sapp/soc512Rotter.pdf, diakses 2 Juli 2016).

Sarwono, S. W. 2012. Pengantar Psikologi Umum. Jakarta: Rajagrafindo Persada.

Sobur, A. 2003. Psikologi Umum. Bandung: Pustaka Setia.

Sternberg, R. J. 2008. Psikologi Kognitif Edisi Keempat. Terjemahan oleh Yudi Santoso. Yogyakarta: Pustaka Pelajar.

Suryabrata, S. 2012. Psikologi Pendidikan. Jakarta: Raja Grafindo Persada.

Syah, M. 2001. Psikologi Belajar. Jakarta: Logos Wancana Ilmu.

Titrarahardja, U. dan La Sulo, S. L. 2008. Pengantar Pendidikan. Jakarta: Rineka Cipta. 